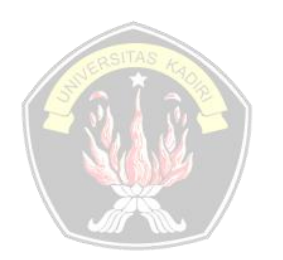

Tersedia online di

"http://ojs.unik-kediri.ac.id/index.php/ekonika"

http://dx.doi.org/10.30737/ekonika.v6i1.939

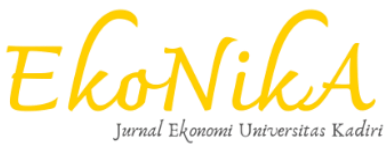

\title{
Analyzing The Effect Of Bank Characteristic On Profitability In Banking Companies Listed In Indonesia Stock Exchange
}

Serly

\section{Fakultas Ekonomi Universitas Internasional Batam}

email: serly.serly.lee@gmail.com

\section{Artikel History:}

Artikel masuk

Artikel revisi

Artikel diterima

\section{Keywords:}

Profitability

Bank Characteristics

Insolvency risk

\section{ABSTRACT}

This research is conducted to analyze the effect of bank characteristics on go public banks' profitability in Indonesia. Return on asset, return on equity, and net interest margin are dependent variables in this research and involves five types of banking risks (credit, liquidity, security, capital, and insolvency), bank size and diversification, and cost efficiency. Research objects of this research are banking companies listed on Indonesian Stock Exchange (IDX). The research data is financial data issued by IDX from 2014 to 2018. Observation data collected in this research is processed using the regression panel method. The result from this research is that credit risk and insolvency risk has effect on return on asset and return on equity significantly. Liquidity risk, capital risk and bank size don't have significant effect. Security risk and bank diversification effecting net interst margin significantly. Cost efficiency has effect on profitability significantly.

\section{INTRODUCTION}

According to the World Bank, Indonesia has increased its value of Gross Domestic Product (GDP) by 5.0 percent in 2016 to 5.1 percent in 2017. As reported from Towards Inclusive Growth (Bank, 2018), several factors have increased GDP and boosted the economy in Indonesia which are investments, net exports, and increasing commodity prices. In connection with these various factors, banking institutions also take a very important role to help improving the economy in Indonesia.

Based on banking regulating policies, namely the Law of the Republic of Indonesia Number 7 of 1992 concerning Banking, in which banks, which are referred to as institutions for collecting and channeling funds from customers for other customers, are required to maintain the level of banking soundness that is adjusted to several provisions such as capital adequacy, asset quality and management, as well as other aspects connected to banking. Evaluation of the 
soundness of banking is carried out directly by banking management. The assessment should be based on general principles. It must be structured, comprehensive, significant, based on materiality and proportionality, and risk oriented.

To assess the soundness of a bank, an analysis of financial statements is needed, for example using CAMEL analysis, which is an analysis method that uses financial ratios. CAMEL analysis is part of risk measurement that can predict the calculation of financial distress experienced in the past, present, or future of the annual report to increase profitability (Munir \& Bustamam, 2017). CAMEL analysis can help internal and external management in making decisions about banking performance. For banking, this analysis focuses more on the aspects of Capital Adequacy, Asset Quality, Management, Equity, and Liquidity.

CAMEL analysis conducted by a bank can help banks know the potentials that have been achieved and the shortcomings that are becoming the weaknesses of the bank company itself. The evaluation conducted after analyzing the banking financial statements is expected to be able to mitigate risks experienced both in the past and in the future, to increase cost efficiency, and other positive expectations to maintain economic stability in Indonesia. However, this focus requires special attention from the banking management (Munir \& Bustamam, 2017).

One source of banking income is interest earned from the customers' lending. However, this source has a risk to the level of the bank's soundness. It can affect the bank's good or bad performance. However, the level of risk is usually directly proportional to the rate of return or profit.

On the other hand, liquidity risk also needs attention to improve bank profitability. Profitability and liquidity have a relationship that attracts one another (Samad, 2015). Therefore, good and proper risk management is needed to maintain the existence of banking businesses. In addition to credit risk and liquidity risk, various risks and other characteristics can also be considered to have a significant relationship with the soundness of banking.

The World Bank stated that the trend of the risks to the prospects for economic growth in Indonesia tend to be sloping downward. On the external side, there is a risk that the recovery of global trade which has just begun can be stopped by increasing protectionism. It has a direct effect on the growth and exports in Indonesia. Inflation that is faster than expected can trigger unexpected monetary tightening which causes fluctuations in capital outflows in Indonesia's 
economy. Banking in Indonesia as the driver of the country's economy should maintain its existence by maintaining soundness in accordance with applicable policies (Bank, 2018).

\section{LITERATURE REVIEW}

\section{Profitability}

One of the interesting things for investors to invest in banking is profitability. Menicucci and Paolucci (2016) explain profitability as the ability of a bank to maintain profits earned from year to year. Profitability also shows the ability of banks to produce new resources from daily operational activities over a certain period of time (Luqman, 2014; Angraini \& Prastiwi, 2020).

Most banks and other financial institutions use ROA as the main measure of profitability. Saeed and Zahid (2016) states that ROA owned by banks shows the level of net profit earned. In addition, ROA also determines the competence and ability of banks in managing their assets to generate profits. Every bank always strives to achieve higher ROA to improve its performance. The driving factor is the assessment factor. It can be concluded that the company's performance is good along with the high value of ROA. Investors will certainly glance at companies with high ROA values because high ROA is able to produce greater level of profit.

Profitability ratio that shows the effectiveness of banks in generating profits from capital or funds invested by shareholders, expressed as a percentage, is called ROE. Not all previous research considers ROE as an effective measure of bank profitability. Fidanoski, Choudhry, Davidović, and Sergi (2018) revealed that ROE has a vulnerability to accounting and managerial actions, namely creative accounting and manipulative practices regarding the distribution of profits. In addition, ROE is not an appropriate benchmark of profitability because of its insensitivity to strategic actions such as restructuring, mergers and acquisitions. This ratio was finally considered to have no potential to differentiate the level of efficiency at each bank. Regardless of the valuation, ROE is still the main performance benchmark for most investors and stock analysts (Nwude \& Okeke, 2018), because this ratio can attract potential shareholders to invest their capital.

In addition to ROA and ROE, another banking profitability ratio is NIM ratio which serves to measure the difference between what banks pay to customers who provide funds and what banks receive from debtors, both individuals and companies (Leykun, 2016). A high NIM 
ratio shows good banking stability. On the other hand, the high NIM ratio can reflect the existence of lending practices that require banks to form a large enough loan loss reserve because the loan has a high credit risk (Raharjo, Hakim, Manurung, \& Maulana, 2014). To assess the effectiveness of NIM in banks, it must be compared with the average NIM in the banking industry. If the NIM has increased above the industry average, it can be said that the bank's NIM is considered effective, and vice versa.

\section{Bank Characteristics}

There are several bank-specific characteristics that might have an influences to profitability such credit risk, liquidity risk, security risk, capital risk, insolvency risk, bank size, bank diversification, and cost efficiency.

Munir and Bustamam (2017) stated that credit risk is the measure of the capital to manage the risk based on the value of the assets owned by banks. Liquidity position and sensitivity to market risk of the two different banking groups (Rekik \& Kalai, 2018).

Securities loan is one type of productive assets owned by banks. When banks invest, for example, banks make investments in other companies, they will increase profits. Staikouras, Mamatzakis, and Koutsomanoli-Filippaki (2008) shows that this ratio is positively related to profitability. Insolvency risk is a condition when the company may not be able to pay its debts. The greater risk of bankruptcy can occur when individuals or companies have little or no cash flow, or poor management of their assets.

Bank size is matters for banks. The impact of bank size to profitability while market gives more explanation at the level of competition in the market (Yuanita, 2019). There is an increase in the proportion of non-interest operating income when compared to the income received from lending activities to customers. In other words, bank diversification can reduce bank profitability. Yuanita (2019) mentioned that cost efficiency is the most widely indicator to increase profitability. Cost efficiency will produce higher profit and will gain more market share.

\section{The Effect of Credit Risk on Profitability}

The risk of bank customers' failure to meet obligations is called credit risk. The obligation in question is the customer's obligation in terms of paying installments or loan to the 
bank (Badawi, 2017). This type of risk is generally found in all banking activities which performance depends on the performance of partners, issuers, or borrowers.

From the understanding of credit risk explained previously, it can be concluded that credit risk and profitability are closely related. If many customers are unable to repay loans, the bank will have difficulty in generating profits. It proves that the high credit risk causes a decrease in bank profitability. The results of the study in which credit risk negatively affects profitability are shown by Isanzu (2017), Tan et al. (2017), Fidanoski et al. (2018), Supriyono and Herdhayinta, (2019). While positive significance was obtained in the study of Leykun (2016) who argue that banks charge additional risk premium cost to compensate credit risk.

$\mathrm{H}_{1}$ : Credit risk is negatively associated with the profitability of listed firms in Indonesia

\section{The Effect of Liquidity Risk on Profitability}

Liquidity risk is a type of risk that indicates that the bank is in a condition of being unable to meet the customer's cash demand. This risk can result in significant loss and profit reduction (Arif \& Anees, 2012).

The relationship between liquidity and profitability is like a tug of war (Samad, 2015). When banks hold more assets in the form of cash reserves in their vaults, it will be more liquid and safer to pay customer claims for deposits. However, it will disrupt banking profitability. On the other hand, profitability can increase when banks invest in long-term loans. This will make banks vulnerable because they cannot meet the customers' demand for large amounts of cash and the provision of funds in connection with loans from new customers.

Profitability will increase with the number or amount of loans given by banks to their customers. Fidanoski et al. (2018) found that liquidity risk can increase profitability. Kapaya and Raphael (2016) revealed that liquidity is an important internal condition for banks to be able to provide credit. Therefore, higher liquidity must encourage higher profitability. This is because large funds owned by banks can be channeled to customers as borrowers or invested in shares that can provide large income.

Hakimi and Zaghdoudi (2017) have different statement. Banks with insufficient liquidity may experience a decrease in income from loan activities resulting in decreased interest income. Decrease in interest income leads to a decrease in interest margins and banking performance. In addition, insufficient liquidity can reduce the bank's reputation and customer confidence if it cannot meet withdrawal requests.

$\mathrm{H}_{2}$ : $\quad$ Liquidity risk is positively associated with the profitability of listed firms in Indonesia 


\section{The Effect of Security Risk on Profitability}

Securities loan is one type of productive assets owned by banks. When banks invest, for example, banks make investments in other companies, they will increase profits. The higher the value invested, the higher the profitability that can be achieved. Staikouras, Mamatzakis, and Koutsomanoli-Filippaki (2008) shows that this ratio is positively related to profitability. The greater amount of funds invested can increase profitability. However, this relationship becomes negative if the bank does not invest much in securities by sacrificing the loans issued (Rekik \& Kalai, 2018).

$\mathrm{H}_{3}$ : Security risk is positively associated with the profitability of listed firms in Indonesia

\section{The Effects of Capital Risk on Profitability}

Capital risk occurs due to the decline in asset quality, which is caused by bad credit. This makes the bank expand capital by either issuing new shares, injecting capital by shareholders, or attracting new investors to improve their capital condition.

Capital risk should have an effect that can increase profitability. This is evidenced in research with a sample of banks in Croatia by Fidanoski et al. (2018) which found that banks with a stronger capital base show their ability to balance between equity and assets held. According to Angraini and Prastiwi (2020) capital risk has a positive effect on profitability.

Other studies have found the negative impact of capital risk on profitability. According to Tan et al. (2017), the fact that can explain the negative impact is the reduction in the cost of funding at banks with higher capital levels. In addition, banks with higher capital levels have a tendency to prudent lending which can result in higher profitability. In addition, banks that reduce loan volumes receive higher profitability.

$\mathrm{H}_{4}$ : Capital risk is positively associated with the profitability of listed firms in Indonesia

\section{The Effect of Insolvency Risk on Profitability}

Insolvency is the inability of a company to repay debt on the time specified or a condition which occurs when the amount of liabilities exceeds the amount of assets of the company (Pervan et al., 2015). Insolvency risk, also known as bankruptcy risk, is a condition when the company may not be able to pay its debts. The greater risk of bankruptcy can occur when individuals or companies have little or no cash flow, or poor management of their assets.

Z-score is a tool or formula that can assess insolvency risk owned by each bank. A higher Z-score indicates a lower risk of insolvency and greater stability, and vice versa. Z-score has been widely used to measure the stability of financial institutions, especially banks. 
In the investigation conducted by Pervan et al. (2015), and Tan et al. (2017), it was found that the risk of insolvency affected profitability with a positive significance. According to Pervan et al. (2015) banks having more capital than assets are able to achieve higher levels of profitability.

$\mathrm{H}_{5}$ : Insolvency risk is positively associated with the profitability of listed firms in Indonesia

\section{The Effect of Bank Size on Profitability}

The number of assets in the bank is used as a reference to assess the size of the bank. The size of the bank has been extensively studied and it has been found that it has a variety of significance to profitability. A study conducted by Tran et al. (2016), Angraini and Prastiwi (2020) showed that bank size is positively related to profitability. It was found that the greater amount of assets can increase the profitability of a bank. Tan (2016), found that bank size affects profitability with a negative significance. According to Menicucci and Paolucci (2016), very large bank size is possible to have a negative relationship with profitability, which can be caused by very large costs resulting in losses. The amount of losses suffered by banks can also be caused by some irrecoverable loans.

$\mathrm{H}_{6}$ : $\quad$ Bank size is positively associated with the profitability of listed firms in Indonesia

\section{The Effect of Bank Diversification on Profitability}

The benefits of reducing company-specific risks arise with investment diversification, as stated by portfolio theory. This has encouraged banking management to intensify business diversification. Diversification of the business undertaken is not focused on lending activities, but on business line activities that give public services in investing and also in securities trading, insurance and underwriters. As a result, there is an increase in the proportion of non-interest operating income when compared to the income received from lending activities to customers. In other words, bank diversification can reduce bank profitability, especially in its NIM ratio.

A study conducted by Tan et al. (2017) found that bank diversification has positive significance on ROA which means bank diversification reduces bank costs through the economy field which can lead to an increase in bank profitability. His research also proves that diversification has a negative impact on ROE and NIM which means banks reduce the volume of loans provided. The reduced volume of loans has resulted in reduced income generated by banks so that profitability has decreased.

$\mathrm{H}_{7}$ : Bank diversification is negatively associated with the profitability of listed firms in Indonesia 


\section{The Effect of Cost Efficiency on Profitability}

Cost efficiency in banks often becomes the public spotlight. Banking as a driver of the economy is required to operate efficiently and optimally as a bridge between the owner of the fund with other parties who need loans. Inefficiency can affect the economy of a country in which the country is unable to compete with other countries. The strategic role of the banking system in the economy makes many parties pay great attention to this industry.

The level of banking operational efficiency is measured by the Operational Efficiency Ratio (BOPO). The higher BOPO, which is calculated by dividing operating costs against operating income, shows the low efficiency of the banking industry operation.

$\mathrm{H}_{8}$ : Cost efficiency is negatively associated with the profitability of listed firms in Indonesia

\section{RESEARCH METHOD}

\section{Research Design}

This research is categorized as pure research which means that the research is conducted to obtain new discoveries and to develop knowledge (Kuswanto, 2012). This research is also categorized as comparative causal research. This research examines the causal relationship between two or more variables in one particular phenomenon (Indriantoro \& Supomo, 2015).

\section{Research Objects}

The study was conducted on companies listed on the Indonesia Stock Exchange (IDX). The research sample taken as the object of research is companies on the Stock Exchange selected using the purposive sampling method. This method is conducted by collecting research data using several criteria as a condition for fulfilling the sample (Indriantoro \& Supomo, 2015). The data analyzed is the company's financial data recorded in 5 years, from 2014 to 2018. The criteria in determining the sample are:

1. Companies that present complete financial statements on the Indonesia Stock Exchange from 2013 to 2018. The financial statements are downloaded on IDX website, www.idx.co.id.

2. The expiration date of the available banking financial statements is December, 31 .

3. The company's annual financial statements have complete data which are used to calculate all the required variable data. 


\section{Variables}

The variables analyzed are the profitability dependent variables with three measurements including Return on Assets (ROA), Return on Equity (ROE), and Net Interest Margin (NIM), while the independent variables used are 5 types of banking risks (credit, liquidity, securities, capital, and insolvency), bank size and diversification, and cost efficiency.

Below are methods used to measure variables in this research:

Table 1. Variables Definitions

\begin{tabular}{|l|l|}
\hline \multicolumn{1}{|c|}{ Variable } & \multicolumn{1}{c|}{ Measurement } \\
\hline Return on Asset & Return on asset is measured by the net income to total assets. \\
\hline Return on Equity & Return on equity is measured by the net income to total equity. \\
\hline $\begin{array}{l}\text { Net Interest } \\
\text { Margin }\end{array}$ & $\begin{array}{l}\text { Net interest margin is measured by the net operating income to } \\
\text { average earning assets. }\end{array}$ \\
\hline Credit Risk & $\begin{array}{l}\text { Non Performing Loans (NPL) netto: } \\
\text { problem loan-Allowance for impairment losses on non performing loans }\end{array}$ \\
\hline Liquidity Risk & $\begin{array}{l}\text { Liquidity risk is measured by the third party credit non-bank to } \\
\text { third party deposits. }\end{array}$ \\
\hline Security Risk & Security risk is measured by the total securities to total assets. \\
\hline Capital Risk & $\begin{array}{l}\text { Capital risk is measured using Capital Adequacy Ratio (CAR): } \\
\text { total equity to total assets. }\end{array}$ \\
\hline Insolvency Risk & $\begin{array}{l}\text { Z-score are used to estimate the insolvency risk on commercial } \\
\text { bank. }\end{array}$ \\
\hline Bank Size & Bank size is measured as the natural logarithm of total assets. \\
\hline $\begin{array}{l}\text { Bank } \\
\text { Diversification }\end{array}$ & $\begin{array}{l}\text { Diversification bank is measured by the non-interest income to } \\
\text { gross revenue. }\end{array}$ \\
\hline Cost Efficiency & $\begin{array}{l}\text { Cost efficiency is calculated by dividing operating costs against } \\
\text { operating income. }\end{array}$ \\
\hline
\end{tabular}

\section{Data Analysis Method}

This research uses multiple linear regression method. The tests are carried out on the independent variables and their effect on the dependent variables. The research data are analyzed using statistical application, namely Eviews. The tests conducted to answer the research objectives include outlier tests, statistical descriptive tests, and hypothesis tests which include several tests including the $\mathrm{F}$ test, $\mathrm{t}$ test, and the coefficient determinant test. 


\section{RESULT \& DISCUSSION}

\section{Descriptive of Research Object}

The population for the analysis is the company's financial data recorded in 5 years, from 2014 to 2018 listed on the Indonesia Stoch Exchange (IDX). Table 2 provides a summary of the observation data.

\section{Table 2. Observation Data}

\begin{tabular}{lll}
\hline Description & \multicolumn{2}{l}{ Number of firms } \\
\hline Firms listed on IDX & 615 & firms \\
Firms non banking sector & $(570)$ & firms \\
\hline Banking companies listed on IDX & 45 & firms \\
Banking companies outside the criteria & $(7)$ & firms \\
\hline Number of banking companies selected & 38 & firms \\
Number of years of observations & 5 & years \\
\hline Number of observations data & 190 & data \\
\hline
\end{tabular}

The initial sample of the present study comprises all 615 firms listed on the IDX. Further, this research eliminates 570 firms outside the banking company, and 7 firms were excluded because of incomplete data. This selection process results in 38 firms being eligible to be included in the sample. A total of 190 annual reports of 38 companies that made up the sample size were analyzed.

\section{Descriptive Statistics Analysis}

The dependent variable is profitability, which is proxied using the return on asset ratio, return on equity ratio, and net interest margin. The descriptive statistic of variable employed in the present study is reported in Table 3 . 
Table 3. Descriptive Statistics

\begin{tabular}{lccccc}
\hline Variable & $\begin{array}{l}\text { Number } \\
\text { observations }\end{array}$ & Minimum & Maximum & Mean & SD \\
\hline ROA & 190 & 0.000000 & 0.031343 & 0.010176 & 0.008236 \\
ROE & 190 & 0.000000 & 0.247954 & 0.071488 & 0.056093 \\
NIM & 190 & 0.001765 & 0.144715 & 0.064107 & 0.026742 \\
Credit risk & 190 & 0.000000 & 6.370000 & 1.740316 & 1.293690 \\
Liquidity risk & 190 & 0.419869 & 7.944027 & 0.886329 & 0.533452 \\
Security risk & 190 & 0.000409 & 0.337977 & 0.114445 & 0.072395 \\
Capital risk & 190 & 0.052063 & 0.385543 & 0.146608 & 0.051126 \\
Insolvency risk & 190 & 0.000000 & 365.587600 & 39.737870 & 54.952720 \\
$\begin{array}{l}\text { Bank size } \\
\text { (in million) }\end{array}$ & 190 & $1,641,425$ & $1,296,898,292$ & $141,540,828$ & $259,832,511$ \\
Bank diversificat: & 190 & 0.008052 & 0.580514 & 0.126224 & 0.091158 \\
$\begin{array}{l}\text { Cost efficiency } \\
\text { (BOPO) }\end{array}$ & 190 & 0.525061 & 1.632441 & 0.852155 & 0.171411 \\
\hline
\end{tabular}

The bank with negative profit and suffer losses is considered to have zero percentage of ROA and ROE. This condition shows that the bank does not have the ability to return the asset or equity from the profit generated. Table 2 shows the minimum percentage of ROA and ROE is $0.00 \%$, which explains that not all banks in Indonesia gain profits from 2014-2018.

The net interest margin is related to the average earning asset. The average net interest margin achieved by banks in Indonesia in this research is 0.064107 . The minimum NIM is $0.1765 \%$, with a maximum of $14.4715 \%$, an average of $6.4107 \%$. Banking authorities set the standard for NIM at under $5.00 \%$. This means the majority of sample in this study exceeds the standard.

Credit risk is measured by the net non-performing loans at each bank. Bank with the credit risk value of 6.37 indicated have unhealthy credit activity with customer partially have bad credit (substandard, doubtful, and bad). The majority of bank in this study meet the maximum NPL percentage set by the banking authority, which is $5.00 \%$. This can be a subject for attention by bank's management and the banking regulator.

Liquidity is measured by the loan to deposit ratio (LDR) which is calculated by comparing the total loans to the total deposits. The minimum LDR is $41.9869 \%$, with the mean of $88.63 \%$. The sample in this study is still within the criteria that the banking authority sets the 
standard of LDR between $78 \%-100 \%$. A high liquidity ratio indicates that the bank's biggest source of income is obtained from credit. The lower LDR is an indication of an increase in the funds from third-party and signals that the bank has a higher total deposit compared to the total credit.

From the table 2, the security risk was found to be $11.44 \%$, which was an indication that the banks generated income from their investments. The minimum CAR of our sample is $5.2063 \%$, with a maximum of $38.5543 \%$, a mean of $14.6608 \%$, and the standard deviation is $5.1126 \%$. The minimum CAR set by the banking authority is $8.00 \%$ that means all samples in this study beyond expectation.

Z-score is a tool or formula that can assess insolvency risk owned by each bank. A higher Z-score indicates a lower risk of insolvency and greater stability, and vice versa. The minimum insolvency risk was found to be $0.00 \%$.

This study uses the total asset as an indicator. Since the amount of total assets varies widely among banks, this research uses the natural logarithm of the total asset to mitigate data skewness. The minimum bank size is Rp1,641,425 million, the maximum is Rp1,296,898,292 million.

The minimum bank diversification of our sample is $0.8052 \% \%$, with a maximum of $58.0514 \%$, a mean of $12.6224 \%$, and the standard deviation is $9.1158 \%$. Further, the minimum cost efficiency (BOPO) is $52.5061 \%$, with a maximum of $58.0514 \%$, an average of $12.6224 \%$. If the BOPO is above the standard (not to exceed $92 \%$ sets by banking authority), it means the bank's operation is less efficient and needs to be improved by the bank's management.

\section{F-test Statistics}

The F-test is carried out about its significance on Prob F-statistic. In this test, a significance value of 0.000000 was obtained for the three dependent variable proxies. Therefore, it can be said that all independent variables simultaneously affect each dependent variable. The $\mathrm{F}$ test results are as follows:

Table 4. F-test Statictics

\begin{tabular}{ccl}
\hline Measurement & Sig. & Result \\
\hline ROA & $0,00000($ & Significant \\
ROE & $0,00000($ & Significant \\
NIM & $0,00000($ & Significant \\
\hline
\end{tabular}




\section{T-test Statistics}

The t-test show the effect produced partially or each of the independent variables on the dependent variable. This test is also intended to find the correlation coefficient between the independent variable and the dependent variable.

Table 5. T-test statistics (ROA Model)

\begin{tabular}{llll}
\hline Variables & Coefficients & P-Value & Result \\
\hline Credit risk & -0.000769 & $0.0029 *$ & Supported \\
Liquidity risk & 0.000246 & 0.5116 & Not supported \\
Security risk & -0.006693 & 0.2571 & Not supported \\
Capital risk & 0.014025 & 0.0772 & Not supported \\
Insolvency risk & 0.000151 & $0.0000^{*}$ & Supported \\
Bank Size & 0.001128 & 0.2901 & Not supported \\
Bank diversification & -0.004582 & 0.2543 & Not supported \\
Cost efficiency & -0.008771 & $0.0009 *$ & Supported \\
\hline Significant level at 0.05 (p-value) & &
\end{tabular}

Table 6. T-test statistics (ROE Model)

\begin{tabular}{llll}
\hline Variables & Coefficients & P-Value & Result \\
\hline Credit risk & -0.007872 & $0.0000^{*}$ & Supported \\
Liquidity risk & 0.001488 & 0.5805 & Not supported \\
Security risk & 0.002331 & 0.9560 & Not supported \\
Capital risk & -0.073990 & 0.1925 & Not supported \\
Insolvency risk & 0.001573 & $0.0000^{*}$ & Supported \\
Bank Size & 0.003677 & 0.6301 & Not supported \\
Bank diversification & -0.021001 & 0.4656 & Not supported \\
Cost efficiency & -0.046000 & $0.0147 *$ & Supported \\
\hline
\end{tabular}

*Significant level at 0.05 (p-value) 
Table 7. T-test statistics (NIM Model)

\begin{tabular}{llll}
\hline Variables & Coefficients & P-Value & Result \\
\hline Credit risk & 0.001584 & 0.1277 & Not supported \\
Liquidity risk & -0.001047 & 0.4942 & Not supported \\
Security risk & 0.072824 & $0.0028^{*}$ & Supported \\
Capital risk & 0.039964 & 0.2155 & Not supported \\
Insolvency risk & 0.000109 & 0.2218 & Not supported \\
Bank Size & 0.002211 & 0.6106 & Not supported \\
Bank diversification & -0.076016 & $0.0000^{*}$ & Supported \\
Cost efficiency & -0.041367 & $0.0001^{*}$ & Supported \\
\hline
\end{tabular}

*Significant level at 0.05 (p-value)

\section{H1: Credit risk is negatively associated with the profitability of listed firms in Indonesia}

Table 5 dan 6 shows that credit risk has a negative effect on ROA and ROE. The result indicates that as expected, the association between credit risk profitability is negative and significant, suggesting that an increase in high-risk loans results in a decrease in profitability. This is because of the failure of the debtor to fulfill its obligations to the bank. This result is consistent with the previous studies (Ashraf et al., 2014; Fidanoski et al., 2018; Isanzu, 2017; Kristianti \& Yovin, 2016; Pervan et al., 2015; Samad, 2015; Tan et al., 2017; Supriyono \& Herdhayinta, 2019). On the other hand, this study found that credit risk had no significant affect NIM. This result was in line with Raharjo et al. (2014), Hakimi and Zaghdoudi (2017), Badawi (2017), Nwude and Okeke (2018), Rekik and Kalai (2018).

\section{H2: Liquidity risk is positively associated with the profitability of listed firms in Indonesia}

As seen from the results, liquidity risk has no significant association with profitability in all models. This implies that the liquidity risk does not explain the variation of profitability among Indonesia banking companies. Hence, hypothesis 2 in relation to liquidity risk is rejected. The result does not support our prediction. This proves how liquid a bank is, the level 
of profitability will not be significantly affected. This finding confirm many previous studies (Naifar, 2010; Raharjo et al., 2014; Kristianti \& Yovin, 2016; Sun et al., 2017; Badawi, 2017; Alarussi \& Alhaderi, 2018). Badawi (2017) argues that the effect of liquidity risk is not significant because bank liquidity has a different capacity on profitability. This is inconsistent with Samad (2015), Tan et al. (2017), and Fidanoski et al. (2018) who found a positive association between liquidity risk and profitability. Positive significance is generated because banks have liquid resources to invest to increase profitability. In addition, large liquidity is able to provide credit to customers (debtor) who can make higher profitability (Kapaya \& Raphael, 2016).

\section{H3: Security risk is positively associated with the profitability of listed firms in Indonesia}

The third hypothesis shows that the relationship between security risk and ROA also ROE is statistically insignificant with negative direction. According to Rekik and Kalai (2018), the negative relationship can occur when banks do not invest much in securites and sacrifice the loans. On the other hand, security risk has a positive effect on NIM. Fidanoski et al. (2018) stated that security risk had a significant positive impact on NIM. This study also explain that the greater the amount of funds invested can increase bank's profitability.

\section{H4: Capital risk is positively associated with the profitability of listed firms in Indonesia}

This study found capital risk did not influence the profitability in companies listed on the Indonesia Stock Exchange. This result is consistent with the previous studies (Hakimi \& Zaghdoudi, 2017; Kristianti \& Yovin, 2016; Naifar, 2010; Raharjo et al., 2014). This is in contrast with Muriithi et al. (2017) and Tan et al. (2017), who argued that the capital risk has a significant negative effect. Tan et al. (2017) find the facts that can explain the negative impact are the reduction in funding costs, the tendency of prudent lending, and the reduction in loan. Fidanoski et al. (2018) emphasis that banks with a stonger capital base can maintain the balance between equity and asset. These reason are supported by the finding of Nouaili et al. (2015), Leykun (2016), Alharbi (2017), Isanzu (2017), and Sun et al. (2017). 
H5: Insolvency risk is positively associated with the profitability of listed firms in Indonesia

The result in table 5 and 6 indicated that there is a statistically positive significant relationship between the insolvency risk and ROA also ROE. This result is consistent with prior studies (Pervan et al., 2015; Tan et al., 2017). Pervan et al. (2015) stated that have more capital than their assets can achieve higher levels of profitability. In contrast, according to table 7, there is no significant relationship between variable of insolvency risk and NIM (profitability). The result is consistent with Nouaili et al. (2015).

\section{H6: Bank size is positively associated with the profitability of listed firms in Indonesia}

Hypothesis 6 predicts that there is a positive relationship between bank size and profitability. The result in table 5, 6, and 7 indicate that there are a statistically insignificant, thus, rejecting $\mathrm{H}_{6}$. On one hand, greater size may generate economies of scale and has a significant impact on profitability. Various studies identify that bank size can increase the level of profitability by investing their asset in the form of loans to debtor or investing in other firms. These finding conform to a study by Naifar (2010), Samad (2015), Hakimi and Zaghdoudi (2017), and Sun et al. (2017) that studied the effect of bank size and profitability and concluded that therewas no correlation between the two. However, Pervan et al. (2015), Saeed and Zahid (2016), Tran et al. (2016), Tan et al. (2017), Alarussi and Alhaderi (2018), and Fidanoski et al. (2018) found a positive association between bank size and profitability. Positive significance results indicate the greater the number of assets can increase the profitability of banks.

\section{H7: Bank diversification is negatively associated with the profitability of listed firms in Indonesia}

We tested whether bank diversification affects profitability. No significant association was found between bank diversification and ROA. The result also found an insignificant impact between bank diversification and ROE.

Next tested whether bank diversification affects profitability. We found a significant negative association between bank diversification and profitability. Hence, we can say that the net interest margin ratio is directly related to the interest income obtained by banks. This result states that banks that diversify will get a lower net interest margin value. Bank diversification is carried out by banks that do not focus on activities such as lending (credit) to the public, but 
their activities are extended to the public service business in investing. So the income that will be received by banks in the form of non-interest income.

The effect of diversification which has a negative impact on net interest margin is supported by Tan et al. (2017) which argues that the influence of diversification which has a negative impact is caused by banking activities which reduce the volume of loans. The reduced volume of loans has resulted in reduced income generated by banks so that profitability has decreased.

\section{H8: Cost efficiency is negatively associated with the profitability of listed firms in Indonesia}

In models 4,6 , and 7, it can be observed that cost efficiency (BOPO) has significant negative association with profitability. Hence, hypothesis 8 in relation to cost effeciency is accepted. BOPO as reflected in the term, is calculated based on the ratio of operating costs to operating income. A high BOPO indicates that the bank is less efficient. The higher BOPO, the lower the profitability of the bank. The result is consistent with the previous studies (Fidanoski et al., 2018; Kristianti \& Yovin, 2016; Sun et al., 2017; Pervan et al., 2015; Samad, 2015).

\section{Goodness of Fit Model}

Table 8. Adjusted $\mathbf{R}^{2}$ test

\begin{tabular}{cc}
\hline Profitability measurement & Adjusted $R^{2}$ \\
\hline ROA & 0.916783 \\
ROE & 0.907728 \\
NIM & 0.868776
\end{tabular}

The table shows the association between profitability and the independent variables. The summarised results of the dependent variable (ROA, ROE, and NIM) can be see in the table 8. The adjusted R-square of ROA is $91.6783 \%$, ROE is $90.7728 \%$, and NIM is $86.8776 \%$. Both of these values suggest that a significant percentage of the variation in profitabilty can be explained by the variations in the whole set of independent variables.

\section{CONCLUSION}

This study analyzes empirically the bank characteristic on the profitability in Indonesia for the period 2014 to 2018 using 190 data observations. This study concluded that 
this characteristic enhances bank profitability, in terms of ROA, ROE, and NIM. It was found that credit risk had a statistically significant effect in the case of ROA and ROE. Security risk had a statistically significant effect in the case of NIM. Tables 5 and 6 have shown that insolvency risk significantly and positively affects the profitability in the financial report of Indonesia companies. The cost efficiency (BOPO) is found a significant negative association with profitability.

Furthermore, the study has some implications for firms, investors, regulators, and the public. Based on the data's analysis, this research highlights recommendations for the policymakers. First, some ratio needs to be improved to increase bank performance for example LDR ratio below the bank's authority standard. There are several limitations to this paper as well. The study considers only five years of data. The result may differ accros different years are considered for analysis. Further, future research should focus on research by comparing it with other countries.

\section{REFERENCES}

Alarussi, A. S., \& Alhaderi, S. M. (2018). Factors affecting profitability in Malaysia. Journal of Economic Studies. https://doi.org/10.1108/JES-05-2017-0124

Alharbi, A. T. (2017). Determinants of Islamic banks' profitability: international evidence. International Journal of Islamic and Middle Eastern Finance and Management. https://doi.org/10.1108/IMEFM-12-2015-0161

Angraini, R., \& Prastiwi, M. (2020). Determinants of bank profitability: the case of listed bank on Indonesian stock exchange. Jurnal Bisnis Dan Ekonomi, 3(2), 274-283.

Arif, A., \& Anees, A. N. (2012). Liquidity risk and performance of banking system. Journal of Financial Regulation and Compliance. https://doi.org/10.1108/13581981211218342

Ashraf, R., Associate, R., Abbas, A., Anees, S., Zaidi, H., \& Ahmad, W. (2014). Credit Risk Exposure and Performance of Banking Sector of Pakistan. J. Basic. Appl. Sci. Res, 4(3), 240-245.

Badawi, A. (2017). Effect of Credit Risk, Liquidity Risk, and Market Risk Banking to Profitability Bank (Study on Devised Banks in Indonesia Stock Exchange). European Journal of Business and Management www.iiste.org ISSN (Vol. 9). Online.

Bank, W. (2018). Towards inclusive growth. Indonesia Economis Quarterly.

Fidanoski, F., Choudhry, M., Davidović, M., \& Sergi, B. S. (2018). What does affect profitability of banks in Croatia? Competitiveness Review. 
https://doi.org/10.1108/CR-09-2016-0058

Hakimi, A., \& Zaghdoudi, K. (2017). Liquidity Risk and Bank Performance: An Empirical Test for Tunisian Banks. Business and Economic Research. https://doi.org/10.5296/ber.v7i1.10524

Indriantoro, N., \& Supomo. (2015). Metodologi Penelitian Bisnis untuk Akuntansi dan Manajemen. Yogyakarta: BPFE.

Isanzu, J. S. (2017). The Impact of Credit Risk on the Financial Performance of Chinese Banks, 2(3), 14-17. https://doi.org/10.18775/jibrm.1849-8558.2015.23.3002

Kapaya, S. M., \& Raphael, G. (2016). Bank-specific, Industry-specific and Macroeconomic Determinants of Banks Profitability: Empirical Evidence from Tanzania. International Finance and Banking, 3(2), 100. https://doi.org/10.5296/ifb.v3i2.9847

Kristianti, R. A., \& Yovin. (2016). Factors Affecting Bank Performance; Cases of Top 10 Biggest Government and Private Banks in Indonesia in 2004 - 2013. Review of Integrative Business and Economics Research, 5(4), 371-378.

Kuswanto, D. (2012). Statistika Untuk Pemula \& Orang Awam. (R. Maulana, Ed.). Jakarta: Laskar Aksara.

Leykun, F. (2016). Factors Affecting the Net Interest Margin of Commercial Bank of Ethiopia. International Journal of Scientific and Research Publications, 6(6), 150161.

Luqman, O. (2014). The Effect of Credit Risk on the Performance of Commercial Banks in Nigeria. SSRN. https://doi.org/10.2139/ssrn.2536531

Menicucci, E., \& Paolucci, G. (2016). The determinants of bank profitability: empirical evidence from European banking sector. Journal of Financial Reporting and Accounting (Vol. 14). https://doi.org/10.1108/JFRA-05-2015-0060

Munir, M. binti B., \& Bustamam, U. S. A. (2017). Camel Ratio on Profitability Banking Performance (Malaysia Versus Indonesia). International Journal of Management, Innovation \& Entrepreneurial Research, 3(1), 30-39. https://doi.org/10.18510/ijmier.2017.314

Muriithi, J. G., Waweru, K. M., \& Muturi, W. M. (2017). Liquidity Risk and Financial Performance of Commercial Banks in Kenya. International Journal of Economics and Finance, 9(3). https://doi.org/10.5539/ijef.v9n3p256

Naifar, N. (2010). The determinants of bank performance: an analysis of theory and practice in the case of an emerging market. International Journal of Business Environment, 3(4), 460-470. https://doi.org/10.1504/IJBE.2010.037602

Nouaili, M., Abaoub, E., \& Ochi, A. (2015). International Journal of Economics and Financial Issues The Determinants of Banking Performance in Front of Financial 
Changes: Case of Trade Banks in Tunisia. International Journal of Economics and Financial Issues, 5(2), 410-417.

Nwude, E. C., \& Okeke, C. (2018). International Journal of Economics and Financial Issues Impact of Credit Risk Management on the Performance of Selected Nigerian Banks. International Journal of Economics and Financial Issues, 8(2), 287-297.

Pervan, M., Pelivan, I., \& Arnerić, J. (2015). Profit persistence and determinants of bank profitability in croatia. Economic Research-Ekonomska Istrazivanja. https://doi.org/10.1080/1331677X.2015.1041778

Raharjo, P. G., Hakim, D. B., Manurung, A. H., \& Maulana, T. N. (2014). The Determinant of Commercial Banks' Interest Margin in Indonesia: An Analysis of Fixed Effect Panel Regression 1. International Journal of Economics and Financial Issues, 4(2), 295-308.

Rekik, M., \& Kalai, M. (2018). Determinants of banks' profitability and efficiency: Empirical evidence from a sample of Banking Systems. Journal of Banking and Financial Economics, 1(9), 5-23. https://doi.org/10.7172/2353-6845.jbfe.2018.1.1

Saeed, M., \& Zahid, N. (2016). The Impact of Credit Risk on Profitability of the Commercial Banks. Journal of Business \& Financial Affairs. https://doi.org/10.4172/2167-0234.1000192

Samad, A. (2015). Determinants Bank Profitability: Empirical Evidence from Bangladesh Commercial Banks. International Journal of Financial Research, 6(3), 173-179. https://doi.org/10.5430/ijfr.v6n3p173

Staikouras, C., Mamatzakis, E., \& Koutsomanoli-filippaki, A. (2008). Cost efficiency of the banking industry in the South Eastern European region. Journal of International Financial Markets, Institutions, \& Money, 18, 483-497. https://doi.org/10.1016/j.intfin.2007.07.003

Sun, P. H., Mohamad, S., \& Ariff, M. (2017). Determinants driving bank performance: A comparison of two types of banks in the OIC. Pacific Basin Finance Journal. https://doi.org/10.1016/j.pacfin.2016.02.007

Supriyono, R. A., \& Herdhayinta, H. (2019). Determinants of bank profitability : the case of the regional development bank (BPD BANK) in Indonesia, Journal of Indonesian Economy and Business, 34(1), 1-17.

Tan, Y. (2016). The impacts of risk and competition on bank profitability in China. Journal of International Financial Markets, Institutions and Money. https://doi.org/10.1016/j.intfin.2015.09.003

Tan, Y., Floros, C., \& Anchor, J. (2017). The proftability of Chinese banks: Impacts of risk, competition and efficiency. Review of Accounting and Finance. https://doi.org/10.1108/RAF-05-2015-0072

Tran, V. T., Lin, C. T., \& Nguyen, H. (2016). Liquidity creation, regulatory capital, and 
bank profitability. International Review of Financial Analysis, 98-109. https://doi.org/10.1016/j.irfa.2016.09.010

Yuanita, N. (2019). Competition and bank profitability. Journal of Economic Structures, (December 2015). https://doi.org/10.1186/s40008-019-0164-0 